Canadian University Music Review

Revue de musique des universités canadiennes

\title{
The Celluloid Waltz: Memories of the Fairground Carousel
}

\section{Teresa Magdanz}

Volume 23, numéro 1-2, 2003

URI : https://id.erudit.org/iderudit/1014518ar

DOI : https://doi.org/10.7202/1014518ar

Aller au sommaire du numéro

\section{Éditeur(s)}

Canadian University Music Society / Société de musique des universités canadiennes

\section{ISSN}

0710-0353 (imprimé)

2291-2436 (numérique)

Découvrir la revue

\section{Citer cet article}

Magdanz, T. (2003). The Celluloid Waltz: Memories of the Fairground Carousel. Canadian University Music Review / Revue de musique des universités

canadiennes, 23(1-2), 62-83. https://doi.org/10.7202/1014518ar
Résumé de l'article

Le présent article développe l'idée que le carrousel forain et la valse sont étroitement liés dans l'imagination populaire. Mais il y a un prix à cette convention culturelle omniprésente. Le déclin de la fréquentation des champs de foire, à partir des années 1920, coïncidait avec la reconstitution historique de tels divertissements et lieux dans les films et la musique. Et le fondement principal de ces images de documentaires dramatisés reposait sur une sorte de mémoire collective populaire, souvent en contradiction avec l'expérience réelle et historique.
All Rights Reserved ( C Canadian University Music Society / Société de musique des universités canadiennes, 2004
Ce document est protégé par la loi sur le droit d'auteur. L'utilisation des services d'Érudit (y compris la reproduction) est assujettie à sa politique d'utilisation que vous pouvez consulter en ligne.

https://apropos.erudit.org/fr/usagers/politique-dutilisation/ 


\title{
THE CELLULOID WALTZ: MEMORIES OF THE FAIRGROUND CAROUSEL ${ }^{1}$
}

\author{
Teresa Magdanz
}

I was watching Mary Poppins on VHS one day with my three-year-old daughter when it suddenly occurred to me that here was a convention so ubiquitous as to be practically invisible-the association of carousel and waltz. As we laughed at the animated penguins struggling to keep up with the gracefully waltzing Julie Andrews and Dick van Dyke, our amusement turned to wonder as the entire ensemble was transformed into a rotating carousel. Immediately I was reminded of one of my daughter's favourite videos. In an episode from the Thomas Engine series called "Make Someone Happy," a toy carousel is animated by the theme song, now arranged in three-quarter time and with a swirling counter-melody. Was this correlation of carousel and waltz as common as it appeared at first hearing?

Curious, I began to make a list of movies, songs, musicals, TV shows, and music boxes using carousels, and I found very few exceptions to the carouselwaltz rule. Because I had stumbled upon such a widespread cine-musical convention, I expected to find a similar critical convergence between the carousel and waltz in actual fairground history. But this was not the case. Not only was the fairground carousel on the wane by 1940 , what with several large amusement outfitters bankrupt and carousel companies producing fewer band organ rolls, but a search of various carousel organ repertoires showed the waltz to be just one of several popular music genres. In fact, the unimaginable variety and sheer volume of musical works arranged for carousel organ highlight the following aspects. Since about 1905 carousel organ arrangers were closely following current trends, arranging tunes from the "hit" parade within months, even weeks, of publication of a particular song. Another critical aspect of the early twentieth-century carousel was the reflection of multi-ethnic North America in musical terms. Along with waltzes by Waldteufel and Strauss, one finds Polish polkas, Cuban dances, Russian folksongs, religious songs, Italian arias, British music-hall tunes, and Sousa marches in the carousel organ catalogues. $^{2}$

1 Material from this chapter appears in my dissertation (University of Toronto, forthcoming). Earlier versions of this paper were read at the following meetings: New York State / St. Lawrence Chapter meeting of the American Musicological Society (AMS), Hamilton, ON, 26-27 April 2003; The Waltz: Re-Examining and Re-Interpreting a Popular Dance (A Symposium in Honour of Robert Falck), Toronto, ON, 1-2 March 2003; University of Toronto Graduate Department of Music Colloquium Series, Toronto, ON, 27 March 2002. I wish to thank Susan Fast and James Deaville for their insightful comments on an earlier version.

2 This observation was made after looking through several catalogues for either fairground organ or 
Increasingly, it appeared that the critical period of the making of the carousel-waltz convention was the 1940s. For example, the staging on Broadway of Rodgers' and Hammerstein's hugely popular stage-musical Carousel (1945) seemed to dovetail with the waning of the fairground, a once major source of entertainment for North Americans from all walks of life. The stage play's opening scene of a riotous fairground, turning carousel, and boisterous crowd was scored by a majestic concert waltz suite. Was this waltz emblematic of the nostalgia for a disappearing way of life? Looking beyond Carousel and in the past I discovered the artistic source from which the creators of Carousel derived the idea for their show was a popular stage play in 1909. Liliom, written by Ferenc Molnár, was a bittersweet romantic fantasy about a carnival barker who is given a second chance in heaven to make up for his transgressions on earth. The play's prologue takes place at a fairground on the outskirts of a big metropolis (Budapest). Though no waltz or mention of one occurs in the play, crucial bits of dialogue emphasize the carousel's sound and its ability to evoke powerful responses in its listeners. During the 1930s the play was twice brought to the screen, and the carousel and its music continued to play a critical role in the world of its characters. In these films, as with others of the period, camera and audio techniques were utilized to represent not only the fairground and carousel but, as well, the very attitudes toward these things as mementos of cherished and past experience. By 1956 and the 20th Century Fox production of the lavish movie-musical Carousel, myth, memory and experience were all but inseparable. When, for example, Billy Bigelow recalls his former life as a carousel barker we are witness to a lost time. As his memory proceeds to a flashback that will occupy the rest of the film, certain cinematic techniques give resonance to his remembrance. The cinematic bleed-in of a new image (lights of carousel), and the gradual cueing in of music (a waltz) that gets louder as the recollection is fully established, all work to mediate, to become the experience-not just for the subject but, arguably, for the audience as well.

In what follows, I explore the making of the carousel-waltz convention beginning with two films from the 1920 s which already evince a profound nostalgia for the peripatetic ways of the circus and fairground. Next, the remarkable trajectory of responses originating with Molnár's play and culminating in the full-blown carousel-waltz convention as seen and heard in Rodgers' and Hammerstein's Carousel is given a central place here. Tracing the lineage of the carousel-waltz correspondence allows me to comment not only on the making of a major musical-visual convention but as well, the role of that convention in the blurring the lines between myth, memory and truth.

As John F. Kasson (1978) has argued in his study of turn-of-the-century entertainment in North America, amusement parks emerged as the premier site in which

theatre player piano repertoire in the Wurlitzer archives at the National Museum of American History, Smithsonian Institution. As well, Caulfield (2003) was indispensable in providing detailed information on the arranging practices and repertoire of the fairground organ. 
the working-classes as well as a steadily growing segment of the middle-class could temporarily escape the hegemony of the older genteel culture. Situated on the Eastern and Western U.S. seaboards, as well as in the American heartland, these new spaces of leisure materialized as "laboratories of the new mass culture, providing settings and attractions that immediately affected behaviour" (Kasson $1978,7)$. In contrast with conventional society and everyday work routine where social behaviour was more closely circumscribed, such places as New York's Coney Island, Boston's Paragon Park, Cleveland's Euclid Beach or San Francisco's The Chutes "plunged visitors into a powerful kinesthetic experience that ... overturned conventional restraints." Critically, Kasson locates the heart of the amusement park experience in a kind of powerful sensorium where smells, tastes, sights, sounds and physical jolts ruled the day. What especially impressed observers, he asserts, was "the din of barkers, brass brands ... merry-go-rounds ... above all else the shouts and laughter of the crowd itself" (Kasson 1978, 49).

By the 1920s fairground attendance was sliding due to the new mass entertainments, particularly the movies, which offered "elaborate, convincing illusions at a price Coney Island could not match" (Kasson 1978, 112). Ironically, these "illusions" often included realistic portrayals of the anarchic freedom of the fairground. Another aspect of socio-cultural change occurring throughout 1920s North America and Europe is harder to document but reveals even more profoundly the eventual erasure of the old ways of life and leisure. David Gross has written of the whole-scale effort to rid city streets and other such public spaces of any traces of nostalgia. According to Gross, no less influential figures than Le Corbusier and Sigmund Freud warned that retaining historical sites would interfere with the practical affairs of everyday life. Freud worried that certain "mnemonic symbols" in the city could lead people to become too wrapped up in the past; similarly, Le Corbusier felt that the modern city should keep no references to the past since they represent a "danger to life" and should be expunged "without remorse" (Gross 2000, 102-3). Up until about 1920, tiny horse-pulled carousels and their noisy organs could be seen and heard throughout both small and large cities in North America. ${ }^{3}$ However, the enactment of strict noise by-laws by the early 1920 s led to the gradual disappearance of these travelling amusement devices. But the popularity of the carousel was being challenged even before this, for it was forced to compete with more thrilling, gravity-defying rides since the first years of the twentieth century. While in Britain the carousel, or roundabout as it is commonly known, fell out of favour during the Edwardian era bouncing back in a fit of Victorian nostalgia in the late 1920s, it is difficult to know how precisely this historical situation mirrors the North American one (Disher 1942; Murphy 1951). It seems clear, however, that any measure of popularity amusement rides such as

3 Two photographs of these tiny moving carousels are held in the Frederick Fried archives of the National Museum of American History, Smithsonian Institution. Both were taken on the Lower East Side of Manhattan circa 1910-20 (photographers unknown). According to the National Carousel Association's Website, smaller towns and counties also saw these travelling carousels (http://www.nca-usa.org/NCA census.html). 
the carousel enjoyed in the 1930s and beyond was due in no small part to the nostalgic impulse.

Throughout the 1920s one could find films whose subject matter revolved around the peripatetic delights of fairground and circus life. Often, the underlying theme was one of freedom and the lack of restraint that such a life seemed to promise. This freedom and the nostalgia for it were represented, at least in the cinema, by the working classes that appeared to move in ways and realms unavailable to the nobility and upper class. In Erich von Stroheim's Merry-GoRound (1923), a young woman (Mary Philbin) grinds the carousel organ for a cruel boss in Vienna's Prater, and becomes romantically involved with a Viennese Count (Norman Kerry). Similarly, in D. W. Griffith's classic Sally of the Sawdust (1925), a disreputable confidence man and his daughter (played by W. C. Fields and Carol Dempster) roam the country while Dempster dallies with a handsome socialite (Alfred Lunt) who in turn wants to slum with the freer, more spirited travelers. Both films reveal a yearning for the less fixed and less disciplining world of the circus/fairground. In both films a carousel-moving or still-figures prominently. In von Stroheim's film it functions as a formal device to introduce and conclude the story in the form of a surreal spinning orb enclosing a grinning devil and symbolizing a turbulent society never quite attaining moral rectitude. ${ }^{4}$ What is most striking about the use of the carousel in both films, however, is its function as an everyday prop around which to dialogue, flirt, have serious conversation, saunter, and perform a multitude of otherwise normal tasks. It is a prop, moreover, for feminine purposes, where the subject may navigate her way through the choppy waters of familial and romantic attachments. In a scene from Griffiths' film titled "Happiness and Heartbreak," Dempster's Sally has a casual conversation with her increasingly love-struck suitor while sitting on the carousel's chariot. She moves about the carousel as an argument breaks out between a fairground official and Lunt over her well-being, grabbing the poles of the carousel and playfully rocking it. Eleven years later, the carousel returns as a nostalgic-laden apparatus on which father and daughter can reminisce about life and love. In the 1936 remake of Sally of the Sawdust called Poppy (dir. A. Edward Sutherland), W. C. Fields once again plays the doting father to daughter "Poppy" (Rochelle Hudson). At one point, the two ride a rickety carousel whose animals and platform move in jerky, spasmodic movements instead of the smooth, majestic motion associated with most cinematic carousels. Staring dreamily into an imagined distance they have a private conversation on this most public of fairground amusements. An unlikely source infuses the scene with nostalgia; although various bits of waltz and two-step can be heard as they emanate from the carousel organ, the creaking sounds of the aged merry-go-round momen-

4 Von Stroheim never finished the film. Universal Pictures' production head Irving Thalberg replaced von Stroheim with the dependable if uninspired Julian Rupert. Merry-Go-Round thus became a symbol of studio hegemony over a single artistic vision, with some critics criticizing Rupert's heavy-handed attempt to soften von Stroheim's cynical portrayal of a decaying society. For a full account of the genesis of this film see Lennig (2000). 
tarily dominate, and moviegoers are challenged to recall such sound-memories of their own.

Within the carousel and circus-themed films of the 1920s the waltz was an occasional partner. Although it was the silent film era, both films had music; von Stroheim's in the form of an original score, and Griffith's as cue sheets for various musical pieces. Merry-Go-Round employed a Viennese-styled waltz as its theme tune, using it chiefly to accompany the experimental photoplay marking the film's various transition points where Mephistopheles is seen standing at the centre of a carousel and laughing at the foolish antics of the human race. Because the film begins with this surreal sound-image, it is difficult to hear the waltz as romantic underlay-even as it plays while Agnes, turning the carousel organ, and the Count exchange flirtatious glances. In Griffith's black-and-white film not a single waltz contributes to the aural landscape of the fairground; in fact, one scene titled "On the Old Job Again" shows several views of the fairground's revolving lit carousel and Ferris wheel scored to a sprightly two-step.

If vestiges of the disappearing Lebenswelten were felt in films of the 1920s, they continued to be acutely apprehended in the cinema of the 1930s. It was as if collective memory reached for the carousel as a touchstone out of fear it would forget a critical part of its past. In 1933 MGM produced a backstage musical which featured one of the most glittering, overdone sound-visions of all: an art-deco glass-beveled carousel of the future rotating and moving up-and-down simultaneously to a glorious Straussian orchestral waltz. In Robert Z. Leonard's Dancing Lady which starred a young dancer (Joan Crawford) determined to "make it big," the carousel-waltz number concludes the final sequence of dance-and-song numbers called "That's the Rhythm of the Day." Nelson Eddy performs a song of the same title and acts as singing host. The high modernism of the various skits and scenes lampoons "old-fashioned" music, as well as the milieu in which it is fostered. Life will pass one by, it is inferred, if one indulges in a stuffy minuet. One of the numbers has bewigged dancers moving in stately Haydnesque silhouettes; once the jazz-inflected "rhythm of the day" begins, the dancers throw off their braid-encrusted gowns to reveal modern urban attire. At the very end of this sequence when the ensemble has done no less than fly to Bavaria on a boom-rigged cloud and danced, drunk beer and cavorted in this new location, "Rhythm of the Day" ends with the elaborate carousel-waltz. Its riders are the lovely chorus girls/ dancers wearing wispy frocks that blow in an inexplicable breeze-inexplicable because the artificial backdrop provides no clue as to the source of the wind. It is curious that the entire sequence ends with the elaborate sound-image of the carousel-waltz. Where on a scale from "mouldy-oldie" to "current" do the carousel and waltz fit? On the one hand, the waltz's melody is a distinct paraphrase of the jaunty, jazzy "Rhythm of the day," is not treated with the typical automated carousel organ sound, and would appear, therefore, to fit in the modern, progressive camp. On the other hand, the waltz's Strauss-like orchestration and melodic structure put it in the nostalgia camp. Symbolically the carousel is even more oblique as it was obviously conceived to point to the future (i.e., a special spotlight highlights the mirrored, streamlined conical 
design). Yet it clearly gives off signs of the past with its sidesaddle riding chorines and the sudden restraint in movement, especially after the earlier, peppy numbers. There is no simple answer to the question. Perhaps the waltz and its carousel encompass both ends of the spectrum - the hopes for the future, as well as a fond (desperate?) glance back. At any rate, it is the waltz alone of all the dances incorporated that is not actually danced, but is animated by mechanical means.

If the message contained in Dancing Lady's art-deco carousel is one of ambivalence, the underlying theme of the entire sequence is not. Nelson Eddy's as well as the other character's exhortations to "get with" the rhythm/music/life of the current era had considerable resonance in broader 1930s society. Gerald Mast has argued that "to musicalize the American spirit in an American setting meant bringing down the $3 / 4$ and $4 / 4$ signatures and running up the $2 / 4$. A truly American theater music ... meant singing that mirrored the ways American[s] talk - and, by implication, feel and think: music that could capture the rhythms, moods, and nuances of contemporary American life" (Mast 1987, 24). Yet waltzes managed to creep into the popular fabric of daily life and cinema and when they did, they were often pointing to something crucial. The waltz-carousel in Dancing Lady may not have represented typical urban values to its audiences, but it revealed how memory and ideas of past collective experience were as critical to the functioning of everyday life as were new ideas and fads.

One thing these films all shared was their visibility in the culture of the day. In other words, these pictures made by well-known directors, producers, composers and other technician-artists in major studios and starring bankable celebrities were seen by a wide audience. This fact alone suggests the enormous appeal and ubiquity of fairgrounds and carousels for an entire generation. However, it was a desire marked by nostalgia for the old freedoms and heedless release places such as Coney Island. This is nowhere more clearly beheld than in the range of responses through the 1930s and 1940s to Ferenc Molnár's play, Liliom. Receiving its inaugural performance in Budapest in December of 1909, Liliom was produced soon after in Vienna, Berlin and London (Györgyey 1980). In 1919, the future director of Casablanca, Michael Curtiz, began shooting a cinematic version but it was never finished. In North America, the play got its first staging on Broadway in 1921, and then again in 1940 starring Burgess Meredith. By 1934, it had merited two notable cinematic adaptations. Approximately ten years later followed the Rodgers and Hammerstein stagemusical interpretation, Carousel. While it would be overstating the case to argue that each new potential film and staged version was directly influenced by its immediate predecessor, I would argue that all "versions" were produced in a constant and growing stream of remembering and nostalgia in which Molnár's play was the source. Liliom may have been a two-bit petty thief who beat his pregnant girlfriend, but for audiences of the 1920s and 1930s his life must have seemed exhilarating. By possessing an interesting job (carousel barker) which did not require him to sit behind a desk, and which enabled him to earn enough money, drink and women to get along, he was able to convey the excitement of the times circa 1900 . In addition, the flashy colourfulness 
and movement of the carousel garnered him the admiration and envy of others. His trouble begins, however, when he discovers Julie is pregnant; he decides to quit his job as carousel barker and look for more lucrative ways to earn money. First, he must break the news to his boss, carousel proprietor Mrs. Muskat:

\section{MRS. MUSKAT}

... and out there is the carousel-and the show booths-and money-and you'd throw it all away. For what? Heavens, how can anyone be such a fool? [Looks at him appraisingly.] Where have you been all night? You look awful.

\section{LILIOM}

It's no business of yours.

MRS. MUSKAT

You never used to look like that. This life is telling on you.

[Pauses.] Do you know-I've got a new organ.

$$
\text { LILIOM }
$$

[Softly.] I know.

MRS. MUSKAT

How did you know?

\section{LILIOM}

You can hear it-from here.

MRS. MUSKAT

It's a good one, eh?

LILIOM

[Wistfully.] Very good. Fine. It roars and snorts-so fine.

\section{MRS. MUSKAT}

You should hear it close by-it's heavenly. Even the carousel seems to know ... it goes quicker. I got rid of those two horses-you know, the ones with the broken ears?

\section{LILIOM}

What have you put in their place?

\section{MRS. MUSKAT}

Guess.

LILIOM

Zebras?

\section{MRS. MUSKAT}

No-an automobile.

\section{LILIOM}

[Transported.] An automobile-. (Molnár 1921, 66-68)

Muskat knows that if she holds any hope of keeping Liliom, her best barker and someone she is powerfully attracted to, she must emphasize the profound 
chasm between the freedom of the fairground, and the monotony of a proper job and home. Her immediate strategy, and one making him pause, is to mention the carousel organ and its sound. Here then is an extraordinary moment between two characters with normally rancorous dealings. Liliom's reaction to the sound also provides the playwright with the means to show the carousel barker's more tender side-something seldom seen throughout the play. Not only do we get a sense of how these characters-and by extension, a larger audience-experienced carousel sound (i.e., up-close as well as from far away), but we can understand how that sound elicited feelings of rapture and the utopian, mixed with nostalgia and a yearning for progress. In addition, the carousel organ's sound is talked about as if it has the power to animate and bring to life the carousel and its animals/autos, and by extension, to awaken profound sensations for carousel riders.

When Fox in 1930 decided to make Liliom into a motion picture it is clear they intended to sell it to a mass audience, for the studio chose Frank Borzage to direct it. Borzage had scored a major success directing the romance Seventh Heaven (1927), an early and popular talkie. Given this fact, and as film critic Dave Clayton (n.d.) argues it is not surprising that Borzage would approach his new project as if filming a love story rather than a faithful adaptation of a well-known play. This accounts for the shift in point of view from the "titular hero" (played by Charles Farrell) to that of the young girl Julie (Rose Hobart). Clayton writes: "The film begins with an astonishing close up of Julie gazing dreamily into space as she puts away glasses in the house where she works as a servant girl. The film's subsequent action all develops out of this opening shot; the adventure Julie will undergo is itself the fulfillment of her romantic longings, the fantasy come true of one great love whose memory will last throughout her life" (Clayton n.d.). These frames no doubt gave later director, Henry King (Carousel, 1956), the idea to present Shirley Jones' Julie in such a manner. Moreover, it seems entirely reasonable to assume that at least a portion of the audience who watched Jones' astonished visage more than twenty years later would also recall Rose Hobart's similarly glazed look.

One other aspect of Borzage's film helped to place it in the realm of the popular in addition to putting into play critical elements of nostalgia, and that was the constant presence of the fairground. Throughout the dialogue of Julie and her friend Marie at the film's beginning we hear the faint strains of the carousel. Like Liliom and Mrs. Muskat who are momentarily transformed by hearing the carousel organ's music, Julie has also been affected by this same sound. Later in the film Liliom, in a pensive mood, is seen standing by the window of his living quarters, looking out at the glittering lights and listening to the carousel organ. Soon after the carousel and fairground are seen and heard for the first time, there is a brief wonderful flash of Julie swaying to the waltz of the carousel organ. As Liliom begins his patter to the fairground attendees, the waltz is heard, followed by a faster two-step. When the lovers first speak to each other, the rotating Ferris wheel and merry-go-round cast alternating patterns of light and shadow on the wall behind. As with the brilliantly back-lit 
shots of the rotating Ferris wheel in von Stroheim's Merry-Go-Round seven years previous to Liliom, the black night makes felt the sight and sound of the spinning amusements all the more viscerally.

In Fritz Lang's Liliom (1934) the flickering shadow of the carousel, the carousel organ's elaborately decorated front (labeled "Hippo-Palace"), and close-ups of an automaton that cranks the music are all seen amidst a velvety, still black night. The first close-up of the automaton initiates a set of three striking frames that literally bleed with remembrance and emotion. In the first, the automaton is motionless, its mouth wide open; in the black stillness of the night, and as a momentary respite from the fairground's ebullience and insanity, it is a sad, lonely and miniature shepherd. The next two frames concentrate on the very details and technology of the carousel organ; first, the cardboard music spilling out of the organ as the organ waltz plays, followed by a shot of the wheel of the organ rapidly turning on its own. How are we meant to see and hear these three somber snapshots, especially as they are sandwiched between extended scenes of Liliom's barking and antics, as well as the rowdy fighting and partying of the youths around and on the carousel? Two things strike the attention of a viewer who watches these images today. First, none of these frames have been shot from a variety of angles or perspective; each is a still-held and singular "snapshot" meant to exhibit, rather than put in play, its subject. Second, all items are smaller working parts of a bigger apparatus, and their momentary separation from the technological whole strives to say something about the awe with which the fairground was regarded. One finds the same attitude toward fairground technology in Lang's earlier work. Siegfried Kracauer comments that most of the fair scenes in The Cabinet of Dr. Caligari (1920) open with an iris-in (small point of light which steadily grows bigger on-screen) revealing an organ-grinder whose arm constantly rotates, and behind him a merry-go-round "which never ceases its circular movement" (Kracauer 1960, 73-74). Is this due to Lang's reverence for details recalled from a childhood spent at Vienna's Prater? Patrick McGilligan suggests that the famous amusement park on Vienna's eastside provided the young Lang with an "adventure through the looking glass." When Lang had moved to Paris in the early 1930s and was handed the screen adaptation of Liliom by Fox's European subsidiary Fox Europa, some colleagues complained of an apparent case of director miscasting. However, and as McGilligan argues, Lang was quite at home "commemorating the Prater" in the process of mounting Molnár's classic (McGilligan 1997, 14-15).

Both Lang's and Borzage's films employ the carousel and Ferris wheel at a formal level, as a key structural device with which to get across the idea that the "spectacle of life itself ... goes on after the death of the individual" (Clayton n.d.). But it is Lang's French-made production alone that utilizes two different waltz themes to mock, empathize with and generally comment on, the action and the character's motivations. For instance, camaraderie between strangers at the fairground is produced when Liliom (played by Charles Boyer) waves his hands excitedly and gets everyone to sing to the tune in example 1a. 
After Liliom is seen leaving the fairground in street clothes (Julie and Marie have waited for him outside while he changes), a waltz tune suggests the sexual

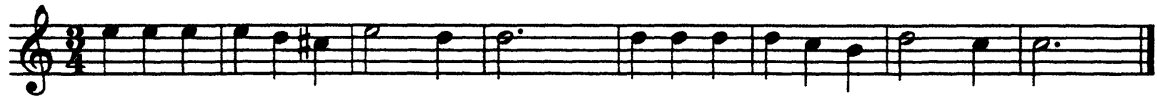

Example 1a. First waltz theme from Liliom (1934) by Jean Lenoir and Franz Waxman

frankness of the ensuing scenes, and is voiced by a wonky, sliding trombone (example 1b).

Later as Liliom's body is laid outside of his shack amidst lit candles, the same trombone waltz is toned down and given angelic metallic sound effects and a

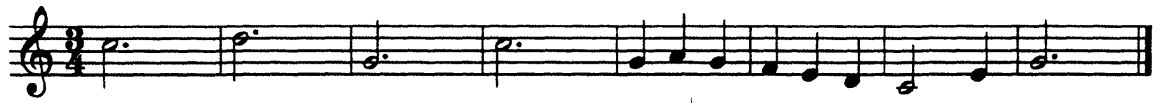

Example 1b. Second waltz theme from Liliom (1934) by Jean Lenoir and Franz Waxman

slower tempo. And finally, the first waltz heard amidst the film's opening black-and-white boxed surtitles and various images of the fairground, is sung at the film's end-this time by Liliom's daughter who is visited by her father from heaven.

Lang's French-language Liliom caused revolts in France instigated in the main by the Catholic clergy and a militant Catholic youth objecting to the portrayal of a "cotton-candy heaven," in addition to the sexual openness of the young people (McGilligan 1997, 199). (One scene on a park bench clearly shows Liliom fondling Julie's breasts.) The superbly shot fairground scenes with their riotous movement and activity, the saucy, naughty waltz tunes underscoring the risky behaviour of youths (both female and male) of ambiguous class and ethnicity essentially represented the moral-less space of the fairground. Similarly, and as Dave Clayton argues, Frank Borzage endeavoured to show the two young lovers caught between the opposing forces of instinctual gratification and social repression. One of the early episodes in Borzage's Liliom shows Julie and Liliom sitting on a knoll above the twinkling lights of the fairground; suddenly, two police officers loom up and block the cinematic frame. Clayton argues that this visual "act of violence," followed by the officers' questioning of Liliom made Borzage's film "as much an attack upon conventional morality and respectability as a glorification of the power of love" (Clayton n.d.). When in Borzage's Liliom the passenger-laden carousel begins to slow down and we hear the synchronized music do the same, the pain of loss and imagined pleasure is palpable. Like the aged creaking carousel in Poppy (1936), Liliom's now still and silent carousel hints at a life that is no more. 
When a real rotating carousel confronts you, the theatre-goer, on stage it is hard not to whistle. As far as stage props go, it is big, it moves, and it thrills. At least this was my experience a few years ago at a local production of Rodgers' and Hammerstein's Carousel. Of course, the carousel did not get to make its own shrill music - this was left to the theatre orchestra. And though the audience never got to experience the reedy, loud, and automated sound of an authentic carousel organ, Rodgers' magnificent waltz with its rising seconds in the melody, brash brass writing, and ear-raising Lydian modality, made sure it was adequately compensated for. But the "Carousel Waltz" conveys so much more. There is the strong aural impression of a village brass band at carnival time created through the simple, measured oom-pah-pah bass, which Rodgers insisted be reinforced by a tuba (Swain 1990, 103). And the actions of the townsfolk of a small 1880s New England village are coordinated to the various sections and climactic points of the waltz. Most important of all, Rodgers' colourful and episodic waltz manages to establish the romantic interest between circus barker Billy Bigelow and mill-worker Julie Jordan, without a word from any of the seventy-plus people on stage.

Carousel was a musical interpretation of Liliom, but with some acute differences. First, the era in which the story takes place was pushed back to the 1880 s. Where the two Liliom films of the 1930s preferred a loosely "now" approach, suggesting the story was contemporaneous with the current day, Carousel's writers were intent on recreating a nostalgic look back at a sunnier epoch-sunnier, that is, than the present (World War Two). Moreover, and as is well documented, ${ }^{5}$ Rodgers and Hammerstein ditched the original Hungarian locale in favour of a small fishing village on the Eastern seaboard. Because the very title of the original play signaled its foreign origins, it too had to go. In its place Rogers and Hammerstein chose a symbol, a kind of aural-visual synecdoche, that could tie all the above threads together as well as evoke the bustling, noisy environment of the fairground. Carousel, then, seemed poised to produce a convention of such power that it would rise and fall (to make a pun) on the strength of its associations. It was not until the arrival more than a decade later of the 20th Century Fox movie-musical that the now firmly established carousel-waltz connection and all that it represented would be tasted and sampled by millions more moviegoers. How precisely did the "Carousel Waltz" manage to solidify a powerful convention, beginning a practice that would see similar kinds of treatments for years to come?

We might consider, for example, that after the first six minutes of the musical no carousel is seen or heard again; in addition, it is the only time we hear Rodgers' concert waltz. Because there is a total absence of dialogue even though the number of people on stage exceeds seventy, it is as if the creators determined to concentrate the intensity of such a symbol within one longish stage moment. In other words, the loud waltz and riotous fairground scene with

5 Several sources discuss the problem of adapting Liliom, among them: Taylor (1953, 179-80), Green (1963, 119-20), Rodgers (1975, 237-38), and Hyland (1998, 157-58). 
its turning life-size carousel are the generators of the entire atmosphere, intensifying its essence rather than spilling bits of it throughout the play. This is all the more noteworthy when one considers that throughout the writing of Carousel, Rodgers and Hammerstein struggled with the opening scene. Initially, the play was to open with an elderly couple, Mr. and Mrs. God, sitting on the porch of their Maine cottage. Unhappy with this lackluster beginning, Rodgers and Hammerstein decided in favour of Molnár's original prologue-a panoramic sweep of the carnival grounds with a large crowd in which jugglers, acrobats, fire-eaters and a rotating carousel were present. What music should accompany this colourful introduction? According to at least one source, the "Carousel Waltz" (or material from it) was percolating in Rodgers' memory for some time before he and Hammerstein put Carousel's prologue together. Richard Hyland, for example, states that one of the "Carousel Waltz" themes was first heard in 1932 in sketches for the movie Hallelujah, I'm a Bum starring Al Jolson (Hyland 1998, 161). Even more fascinating, and as Joseph P. Swain has observed, the entire waltz appears to have been written for a prior project (Swain 1990). In the fall of 1944, bandleader Paul Whiteman commissioned thirteen well-known composers to write instrumental compositions for a radio programme called Music Out of the Blue. ${ }^{6}$ Rodgers began work on a concert waltz with the intended title Tales of Central Park. At this point Rodgers was already deeply involved in the writing of Carousel. Swain believes that Rodgers in a small fit of desperation to find the right musical material for Carousel's opening scene decided to take the waltz he had been composing for the radio programme, and turn it into the prologue for the Theater Guild production. Since, as Swain writes, the Paul Whiteman archives at Williams College contain no recording or arrangement of this concert waltz, and Rodgers makes no mention of the commission in his autobiography, it seems entirely plausible the two waltzes are one and the same (Swain 1990, 99).

The origins of the "Carousel Waltz" are fascinating and reveal how a series of random incidents as well as the collaborative working environment led to the waltz's implementation. As several sources writing about the RodgersHammerstein collaboration make clear, the songwriter and lyricist would never had taken on the musical adaptation of Liliom were it not for the suggestion to do so from the founders and co-directors of the prestigious Theater Guild, Theresa Hellburn and Lawrence Langner. It also could be argued that weekly meetings at Sardi's restaurant in Manhattan with Rodgers, Hammerstein, Hellburn, Langner and a host of other friends and colleagues contributed equally to the ideas fulminating around Liliom/Carousel (Nolan 1979, 124). It appears that Hammerstein was the impetus for the selection of the "Carousel Waltz," for it was Hammerstein alone who in the early spring of 1945 persuaded his partner that "its mood and movement so happily caught the gay and colorful feeling of the opening carousel scene" (Ewen 1957, 239). Two differ-

6Rodgers was in good company; the original list of commissioned composers included Leonard Bernstein, Aaron Copland, and Igor Stravinsky. 
ent realms of creative work-one personal, the other collective-are implied in the putting together of such a large-scale endeavour, and finally, the construction of the carousel-waltz phenomenon. Where do the two meet or are they mutually exclusive? Walter Benjamin described the new collective methods of cultural production, singling out film as the medium par-excellence for open, "detached," and "unconscious" collaboration. In essence he meant that any individual involved in the cinematic process, from the lowliest dolly-grip to the all-powerful director and producers, was motivated to contribute to the script whether through accidental observations, intuitions spoken aloud, or insignificant conversation (Benjamin 1968). I would argue that the process of writing for stage is very similar. Rodgers and Hammerstein revealed that their weekly "gloat" sessions at Sardi's were held primarily to pick up any material or ideas for future projects. In this sense, then, and as Benjamin acknowledged, it becomes difficult to separate the artist-producer from the audience, and thus to know from where the legend-myth of the carousel that revolves in threequarter time originates. Would the audience have paid attention to Carousel's opening prologue scene if another musical genre had been used, such as a march? Could Rouben Mamoulian have directed the crowd scenes so well, and Agnes de Mille set the right tone balletically? Would a pungent nostalgia have been let loose on audiences with expectations riding on the fairground scene if not for the waltz? The decision to use Molnár's carnival/carousel prologue after most of the musical had been written surely had crucial consequences for the making of its most audible and visual symbol. It is as if the opening carousel scene had to be reinvented as a potent collective memory. Not only the public's memory, the personal and collaborative memories of those involved were at stake in this remake of Liliom.

For the theatre lover who had seen Carousel in either of its Broadway or Drury Lane productions beginning in 1945, the 1956 movie-musical would have invited some interesting comparisons. On the one hand, the stage play had begun with a pantomime scene set at a bustling fairground with seventy people on stage on which was mounted a turning carousel. On the other hand, the cinematic story opened in a location far removed from the fairgroundBilly Bigelow is in heaven and is recounting his life on earth to an earnest angel. One consistent feature of both film and stage musical was Rodgers' "Carousel Waltz" and fairground-carousel scenes in both versions were underscored by this music. In the movie-musical, the "Carousel Waltz" is briefly heard as the introductory credits roll. Once the story begins, however, the music is quickly faded out and the audience is left to ponder a fairly silent twilight heaven. Bigelow (Gordon MacRae) is seen sitting perched atop a ladder and as he attaches stars to strings (from a celestial ceiling?), he is called to the magistrate's office to explain why he should possibly be allowed to visit earth for a single day. He then begins to recount his former life on earth as a carousel barker. Soon lost in his reverie, Bigelow describes how the carousel used to go "round and round," and we see his hand movement support his reminiscence. At this gesture, the faint lights of the carousel top are seen as they are slowly 
bled into the existing cinematic frame. Along with these pale glimpses of light is an audio track of band organ sounds-the "authentic" sounds of the carousel. The flashback has begun as the viewer now sees and hears in full colour and volume the whirling merry-go-round set to Rodgers' "Carousel Waltz." However, and as if to "set the scene" for the coming on of the memory, the score begins a few measures before the recapitulation, rather than at the waltz's beginning (example 2 ).

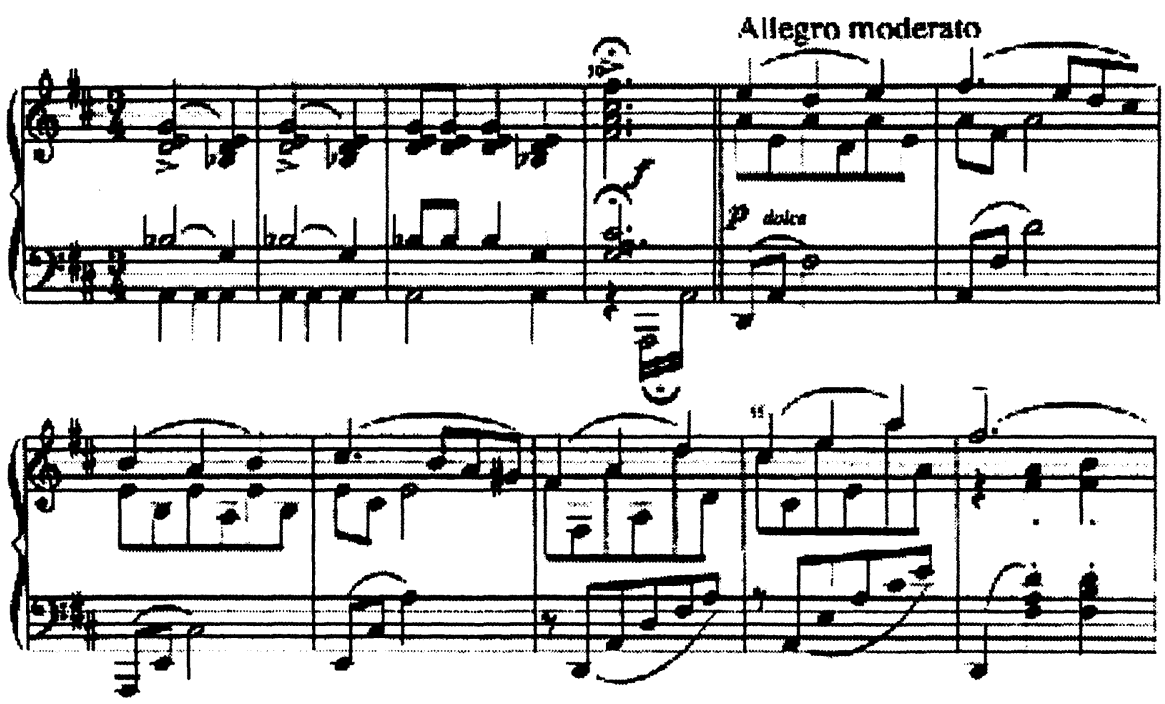

Example 2. "The Carousel Waltz," bars 47-57, from Carousel. Music by Richard Rodgers. (C) 1945 by Williamson Music, copyright renewed. International copyright secured. All rights reserved. Used by permission.

It is not until Bigelow's flashback is fully established with scenes of the fairground and snatches of the waltz playing that we are introduced to Julie Jordan. Most strikingly, the camera's insistence on presenting to us actor Shirley Jones' gaze as she encounters the carousel for the first time seem to create a spectacle on par with the whirling, sounding carousel. Jones' character, Julie, is so astonished that the muscles of her face go slack as she stumbles along the path leading to the carousel. Her amazement as she hears the strains of it churning out the "Carousel Waltz," and as she sees its whirling lit frame is palpable, and I, as the viewer-auditor, am also compelled to accept the spectacularity of that sight and sound. The spectator is given to understand that Julie, living in the dreariness of small-town New England in the 1880s, hungers for something outside her narrow existence. Certainly, the grand orchestral waltz with its sophisticated harmony is just the magical and worldly tonic Julie craves. Miracles can happen, and at this particular moment they do: within a matter of moments she has fallen for circus barker and carousel attendant Billy 
Bigelow. The scene's climax occurs on the whirling carousel. Billy lifts Julie onto a steed gently bobbing in time to the waltz, and the two exchange meaningful looks as the "Carousel Waltz" explodes on a drawn out dominant chord with trumpets blasting. The carousel is the catalyst for Julie's transformation, and it is the carousel waltz that motivates her to act.

Walter Benjamin once commented that the cinema has the peculiar ability to manipulate material, to reveal or represent details of everyday life not normally noticed (Benjamin 1968, 220). Indeed, the cinematic flashback allows the moviegoer the eerie yet familiar sensation of recalling sounds and music culled from imagined or real experience. ${ }^{7}$ The close-up, as well as slow tracking and alternating close-ups of Julie and Bigelow as their facial and bodily expressions are seen, also contribute to psychologically revealing portraits of the habitual. From various overhead boom shots of the fairground, brightly lit carousel, dancing girls on the Bioscope stage and milling crowds, we get slow tracking to a critical narrative moment: Julie's desire to ride the carousel as camera shots alternate between the dumb-struck faces of Julie and Bigelow. It is not until Bigelow has placed Julie on one of the carousel's steeds that we get, first, a close-up of Julie from the waist up, followed by another close-up, this time with Bigelow in the frame standing close by on the carousel's running board. No ordinary close-ups, these frames have been skillfully shot so as to allow visual and aural room to capture the eroticism and sensation of the dizzying speed of the carousel and rushing of the fairground as it whizzes past. Finally, the incongruity between the steady camera and bobbing carousel riders works to cement the relationship between the waltz rhythm and mechanized ride.

If the commonly held notion holds true that we derive much of our factual information from watching movies, what can such sound-images tell us about the way we view our collective past? In addition, and to cite the making of Carousel, if Rodgers, Hammerstein and their numerous "collaborators" were recalling the carousel as sounded by a waltz, what sonic-visual memories were being left behind? In her landmark study of the effects of mass media on personal memories as well as official histories, Marita Sturken maintains that what we choose to recall is highly selective, and "how we retrieve it says as much about desire and denial as it does about remembrance" (Sturken 1997, 7). When we "screen out" certain memories in order to retain others, we are acknowledging the high stakes of attributing meaning to the past (Sturken 1997, 9). Similarly, David Gross argues that the "social frames" of memory dictate what is retained and what is not. When something is remembered over time-again I cite the carousel-waltz phenomenon as a powerful example-the retention, Gross argues, "is not accidental, but purposeful, intentional, and institutionally supported." Furthermore, individuals are encouraged to recall their own past "according to the frames and markers provided by society" (Gross 2000, 77-83). Gross cites seminal work on memory in the 1940 s by Ernest Schachtel for whom virtually every type of memory one may possess is

7For a detailed discussion on how flashback functions in narrative film see Turim (1989). 
formed in sight of markers and signposts provided by the society-at-large (Schachtel 1959). If whole communities are taught the same frames, the everyday world will appear "consistent and harmonious, since everyone will more or less agree on what the past was, and what it continues to mean" (Gross $2000,81)$. By the 1950s, as Gross asserts, the American government was promoting "an 'official' interpretation of the past and in seeing to it that the entire nation shared a similar memory schema" (Gross 2000,121). One aspect of this official interpretation clearly concerned the roles of the sexes. The war had upset notions of women's place in the home what with thousands of women recruited by munitions plants and other large-scale factories. The waltz's longstanding image as a strictly codified dance with male and female partners clearly defined in their movements by the role they enact/play during the length of a dance could play to notions of "official" America. Perhaps it is no surprise, then, that a lavish and nostalgic movie-musical version of Carousel would appear at the moment America was redrafting its image of itself. ${ }^{8}$ At a time when "the ideological web that composes the sign 'America' was being reconstructed and recodified with particular intensity" (Freedman and Millington 1999, 6; May 1988, chap. 1), the carousel and its adaptable waltz worked as a kind of safety valve to keep the lid on strained social relations.

Yet there were other kinds of memory and experience lying beyond these dominant social frames and ones, moreover, the carousel-waltz could so wonderfully voice, namely a poetic and enlivened sense that anything was possible through the utopian whirling circle. Discussing the appeal of actress Julie Andrews for moviegoers of all ages, Richard Dyer argues that her characters (specifically, Mary Poppins / Mary Poppins and Maria / The Sound of Music) are catalyst for the profound sense of the filmgoer's "mastery of the world - that gorgeous sense of sung, danced or 'actioned' expansion in space" (Dyer 1992, 55). A brief summary of the scene(s) I am thinking about from Mary Poppins (1964) will illustrate this point. After Mary, Bert (Dick van Dyke) and the Banks children, Jane and Michael, "disappear" through the pavement chalk-pictures Bert has drawn, the four suddenly appear in a newly created countryside (now animated); the children run off to a distant fairground and the adults set out on an idyllic stroll. The film underscoring is a jaunty two-step (example 3a), smoothly changing into a waltz when the imagery and narrative demand it (i.e., whirling airborne parasol, Bert's whirling of Mary in the air, etc.) (example 3b).

Mary and Bert have been enjoying tea and cakes at a country tea-stand serviced by five animated penguins. After the requisite song-and-dance numbers performed mainly by Bert and the penguins, Mary unfolds her parasol (which seconds later will become the carousel's top), stands up, and holds out her hands to accept her waltz partner's gloved and outstretched hand. At the

8See Biskind (1983) for a more in-depth assessment of how 1950s film contributed to a "cohesive" America. 


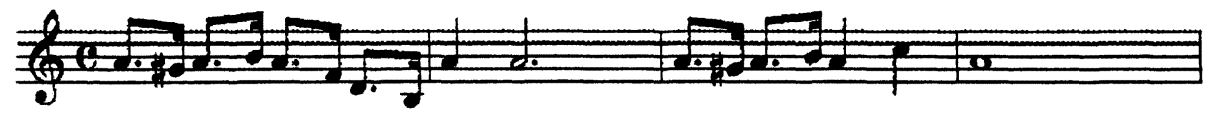

Example 3a. Richard M. Sherman, Robert B. Sherman, lyrics; Irwin Kostal, music; "Jolly Holiday" from Mary Poppins

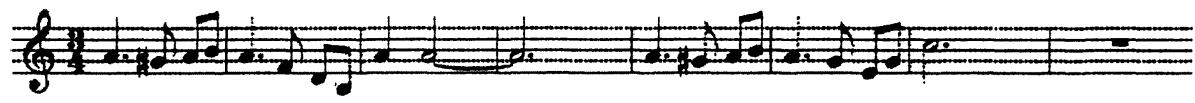

Example 3b. "Jolly Holiday" (waltz) from Mary Poppins

moment the two begin the turning motions for a rather sedate waltz, the raucous cymbal-crashing musical underscoring slips into a delicate musical box waltz. With the penguins sticking close by and energetically hopping up and down, the entire ensemble of human dancers and animals suddenly morphs into a lovely rotating carousel. Jane and Michael, who have magically reappeared, and are seated along with Mary and Bert on two of the four gently bobbing horses, are suitably impressed at having found their "own private merry-goround." For anyone who has watched this scene with a young child or remembers experiencing it at a similar age, the fact of living, breathing penguins turning into magnificent wooden steeds, and more importantly, the thrill of spinning about and transforming oneself into a new entity, are some of the most exhilarating actions imaginable. Even for adults, as Dyer theorizes, such actions on screen seem to imply that taking charge of one's life is possible, simply "through the lilting drive of the tunes" (Dyer 1992, 55). While it could be argued that the dominant frames of memory are at work through the idealized past of 1910s Edwardian England as it mingles with images of the squeaky-clean-courtship of Mary and Bert, the film works equally at keeping alive a resilient creative power by detaching phenomena from their known context and considering them from untold points of view.

In a music-analytical sense, what makes such a moment possible is the pungent déjà-vu manufactured directly through the "lilting drive" of the waltz. Just before the moment of the dancers' transformation to the revolving carousel, two crucial things occur. First, the repetitive pattern of the waltz melody is interrupted by a harmonic and rhythmic change-a diatonically rising melody in quarter notes. As the ascending scale finds its way back to the melody on " $A$ " and a recapitulation of sorts, the tune is "sped up" giving the unmistakable impression of the winding up of a musical box. This, with the added sound treatment (soft tones of the steel comb inside the box), gives an extra phenomenological push to the moviegoer's ability to recall such intimate and cozy childhood moments. Time and the displacement of it are also achieved 
through the interpolation of realist cinematography with animation-a world within a world.

So far I have attempted to lay the foundation for the making of the carouselwaltz phenomenon through such media as film and theatre, and through the ability of audience and artist to recall their own impressions, imbuing their everyday culture with the resonance of these memories. A discussion of some of the schemata at work in memory allowed for the examination of certain themes (i.e., idealized love, and national identity) found in various theatrical and cinematic carousel-waltz combinations. I explored some of the cinematic techniques used in the representation of memory, particularly as they worked in tandem with the carousel-waltz convention. What I want now to discuss is what happens when ideas of the fairground become so enthroned in mass media that they function as cinematic or popular "truth."

Sturken has argued it may well prove impossible to verify the differences between actual or former experience and the kinds of memories constructed through such media as film, stage and television. As an example, she cites numerous accounts of Vietnam veterans who are no longer able to separate their actual experience in battle from the representations so prevalent on television and film. She quotes one ex-soldier as admitting that "what 'really' happened is now so thoroughly mixed up in my mind with what has been said about what happened that the pure experience is no longer there" (Sturken $1997,121)$. Another example concerns the work of psychologists Ulric Neisser and Nicole Harsch who interviewed a group of students the day after the 1986 Challenger explosion in which, among others, schoolteacher Christa McAuliffe died. The students were asked to state where they were and what their reaction was to the event the day after; the students were then reinterviewed several years later. When shown their earlier recollections, most of the subjects were unable to remember them. Significantly, "original" memories had been replaced by what was seen on television or read in newspapers. As Sturken writes: "The insistent television image was ... highly instrumental in rewriting the memory script" (Sturken 1997, 37).

Using Sturken's idea, let us surmise about the kinds of memories in place for movie- and theatre-goers who might have seen various cinematic or stage versions of Liliom, followed by the 1945 stage-musical Carousel, and finally, the 1956 Carousel. The stage-musical "has the capacity to replace personal memories" of, let us say for the sake of argument, Borzage's 1930 Liliom as well as the actual fairground carousel, to "become those memories"; the movie-musical, then, "has the capacity to replace" the earlier stage-musical. Again, and in Sturken's formulation, any later depictions of the carousel-waltz as sound-image are "irrevocably altered" by their "inscription" in the 1956 movie (Sturken 1997, 32). Obviously, many people will not have seen the stage-theatrical version and movie in this order, and many may only have watched the 1956 Carousel. What is critical to note, however, is that a moviegoer's idea or memory of a thing (here, carousel) is predicated on its transformation from, say, actual experience to personal mementos (for exam- 
ple, photographs) to stage and/or moving image. We saw how actual experience on a carousel was amplified (Sturken's term) by camera and sound editing techniques, how the effects of docudramatic reenactment mediated an experience real or imagined.

When we "forget" things we use film to fill in the gaps of our remembrances; more critically, we depend on the docudrama to return them to us in whole form. When in Fritz Lang's Liliom the protagonist, now in heaven, is forced to watch a stop-gap action film of himself hitting Julie, Lang has the heavenly archivist intone: "Film is like a memory, film is stronger than memory." Memory is fragile; by the time we think of preserving certain experience it is often too late. Details may be hard to recall, and there may be gaps in the recollection of experience. Film, then, is the wonderfully efficient and precise record-keeper. But there is another aspect to Lang's dictum, the sense that memory would not exist but for film's presence. If film is stronger than memory, as Lang puts it, it is not properly memory, but something else. Film, then, stands in for memory, and its modes of representation are set to mediate and to structure memory. In other words, as Andreas Huyssen has argued, memory is not possible but for processes of representation:

Re-presentation always comes after, even though some media will try to provide us with the delusion of pure presence. Rather than leading us to some authentic origin or giving us verifiable access to the real, memory, even and especially in its belatedness, is itself based on representation. The past is not simply there in memory, but it must be articulated to become memory. The fissure that opens up between experiencing an event and remembering it in representation is unavoidable. Rather than lamenting or ignoring it, this split should be understood as a powerful stimulant for cultural and artistic creativity. (Huyssen 1995, 2-3)

And it is through this fissure or split that the waltz gains entry, working its way into our collective memories as it seduces us with its presence. Readers will recall from discussion of Carousel (1956), for example, that the juxtaposition of steady camera on tripod (no tracking or movement) with the onrushing and up-down motion of the carousel and riders cemented the connection between waltz and amusement device first intuited in various earlier film and stage representations.

I began this discussion with the assertion that films of the 1920s and 1930s strove to preserve memories of a once mighty mass cultural entertainment, the fairground. And because it possessed the necessary components (i.e., fairground as backdrop, protagonist as barker), Molnár's play Liliom played a key role in the inspiration of future playwrights, composers, and directors. The making of Carousel, first in 1945 as a stage-musical and then in 1956 as a movie-musical was, I argue, the final stage in a gradual process of finalizing, indeed enthroning, a kind of "Kodak" moment of public memory.

As I have attempted to show in this paper, the carousel-waltz pairing has kept alive various critical memories for the collective mass. The dawn of these two entities' entwining coincides roughly with North America's first experience of "a 
less earnest cultural mood ... one more vigorous, exuberant, sensual ... and irreverent" than any time previous (Kasson 1978, 6). By the 1940s and partially due to anxiety over social and political change, this fanciful pairing began to reflect dominant social concerns. It is arguable that by the 1950 s, however, and certainly beyond to the making of such a film as Mary Poppins, such soundvisions began to supply critical information for a generation not always familiar with the old entertainments. Crucially, waltzes and carousels have slipped under the aural and visual radar because their pairing has attempted to carve out a subjectively remembered past, rather than an official historical one. At the root of this remembered, collective past, however, are those first indelible historical moments when applied science-in the form of large mechanized amusements-could playfully tweak as well as wreak havoc on the sensations, movements and forces suggested in various of the expressive arts. Finally, there can be little doubt that the carousel-waltz phenomenon properly belongs to the cinematic age and a visual-or rather visaural ${ }^{9}$-culture hungry for "rhymes" and "cinematic echoes" (Chion 2001, 140). If, as Michel Chion suggests, there is nothing more sublimely cinematic than something turning around on its axis, carousels and their waltzes will be with us for quite some time.

\section{REFERENCE LIST}

Benjamin, Walter. 1968. "The Work of Art in the Age of Mechanical Reproduction." In Illuminations, trans. Harry Zohn, 217-51. New York: Schocken Books.

Biskind, Peter. 1983. Seeing is Believing: How Hollywood Taught Us to Stop Worrying and Love the Fifties. New York: Pantheon Books.

Caulfield, Matthew O., ed. 2003. A Catalog of Music Rolls for the Wurlitzer Military Band Organ Style 165. http://www.wurlitzer-rolls.com (accessed 8 Nov. 2003).

Chion, Michel. 2001. Kubrick's Cinema Odyssey, trans. Claudia Gorbman. London: British Film Institute.

Clayton, Dave. n.d. "An artistically far more satisfying example of the romantic style of direction." Dave's Other Movie Log. http://www.angelfire.com/ movies/davesothermovielog.liliom.htm (accessed 18 July 2003).

Disher, M. Willson. 1942. Fairs, Circuses and Music Halls. London: William Collins.

Dyer, Richard. 1992. Only Entertainment. 2nd ed. London: Routledge. Ewen, David. 1957. Richard Rodgers. New York: Henry Holt \& Co.

Freedman, Jonathan, and Richard H. Millington, eds. 1999. Hitchcock's America. New York: Oxford University Press.

9A term I have created by joining together "visual" and "aural," but with the added sense of "visceral" which is how the new word is pronounced. 
Green, Stanley. 1963. The Rodgers and Hammerstein Story. New York: Da Capo Press.

Gross, David. 2000. Lost time: On Remembering and Forgetting in Late Modern Culture. Amherst: University of Massachusetts Press.

Györgyey, Clara. 1980. Ferenc Molnár. Boston: G. K. Hall \& Co.

Huyssen, Andreas. 1995. Twilight Memories: Marking Time in a Culture of Amnesia. New York: Routledge.

Hyland, William G. 1998. Richard Rodgers. New Haven: Yale University Press.

Kasson, John F. 1978. Amusing the Million: Coney Island at the Turn of the Century. New York: Hill \& Wang.

Kracauer, Siegfried. 1960. From Caligari to Hitler: A Psychological History of the German Film. New York: Noonday Press.

Lennig, Arthur. 2000. Stroheim. Lexington, KY: University Press of Kentucky. Mast, Gerald. 1987. Can't Help Singin': The American Musical on Stage and Screen. Woodstock, NY: Overlook Press.

May, Elaine Tyler. 1988. Homeward Bound: American Families in the Cold War Era. New York: Basic Books.

McGilligan, Patrick. 1997. Fritz Lang: The Nature of the Best. New York:

St. Martin's Press.

Molnár, (Franz) Ferenc. 1921. Liliom: A Legend in Seven Scenes and a Prologue. Eng. text Benjamin F. Glazer. New York: Boni and Liveright.

Murphy, Thomas. 1951. "The Evolution of Amusement Machines." Journal of the Royal Society of Arts 4833, no. 99 (7 September): 791-806.

Nolan, Frederick. 1979. The Sound of Their Music: The Story of Rodgers \& Hammerstein. London: Unwin Paperbacks.

Rodgers, Richard. 1975. Musical Stages: An Autobiography. New York: Random House.

Schachtel, Ernest G. 1959. Metamorphosis: On the Development of Affect, Perception, Attention, and Memory. New York: Basic Books.

Sturken, Marita. 1997. Tangled Memories: The Vietnam War, the AIDS Epidemic, and the Politics of Remembering. Berkeley: University of California Press.

Swain, Joseph P. 1990. "Morality Play as Musical." In The Broadway Musical: A Critical and Musical Survey, 99-127. New York: Oxford University Press.

Taylor, Deems. 1953. Some Enchanted Evenings: The Story of Rodgers and Hammerstein. New York: Harper \& Brothers.

Turim, Maureen. 1989. Flashbacks in Film: Memory and History. New York: Routledge. 


\section{Abstract}

This paper explores the idea that the fairground carousel and waltz are tightly linked in the popular imagination. But this ubiquitous cultural convention has come with a price. The decline in fairground attendance from the 1920s and on dovetailed with the increasing reenactment in movies and music of such entertainments and space. And the prime structure motivating such docudramatic images was a kind of public collective memory, often at odds with actual, historical experience.

\section{Résumé}

Le présent article développe l'idée que le carrousel forain et la valse sont étroitement liés dans l'imagination populaire. Mais il y a un prix à cette convention culturelle omniprésente. Le déclin de la fréquentation des champs de foire, à partir des années 1920 , coïncidait avec la reconstitution historique de tels divertissements et lieux dans les films et la musique. Et le fondement principal de ces images de documentaires dramatisés reposait sur une sorte de mémoire collective populaire, souvent en contradiction avec l'expérience réelle et historique. 